\title{
Students Use More Books after Library Instruction: An Analysis of Undergraduate Paper Citations
}

\section{Rachel Cooke and Danielle Rosenthal}

In fall 2008, students from first-year Composition I and upper-level classes at Florida Gulf Coast University participated in a citation analysis study. The citation pages of their research papers revealed that the students used more books, more types of sources, and more overall sources when a librarian provided instruction. When these results were compared to those produced by students in upper-level classes (all of whom received instruction), it was discovered that, as the class level increased, the number of citations and the percentage of scholarly citations generally increased and there was a high preference for books from all disciplines, especially history.

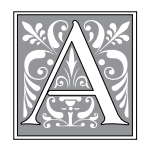

cademic librarians teach information literacy skills to students in a variety of ways: online tutorials, online chat, personal consultations, walk-in reference desk assistance, and in-class library instruction. With all these choices, the traditional in-class library instruction may seem a bit "old school," but there are certainly some key advantages: first, students are already scheduled to be there; second, the instructor (if present) is informed of "what's new" at the library; third, multiple students can be taught at once; and, finally, there is face-to-face immediacy that allows for interaction between librarian and student.

In fact, at Florida Gulf Coast University (FGCU), a Masters I institution with approximately 9,000 undergraduates, we use all the teaching methods above, but the in-class library instruction remains a popular choice with faculty. During the 2008-2009 academic year, FGCU librarians were invited by faculty to teach 1,988 students in 106 in-class library sessions. Obviously, this demands substantial time and resources from the librarians, and assessment of these sessions is ongoing to make sure this time is well spent. To assess the success of these sessions, librarians usually ask students to fill out a questionnaire. However, these questionnaires often gauge the student's feelings rather than assessing core competencies of information searching. For example, the questions would measure how the student felt about the effectiveness of the library session or presenter or the level of engagement in the class, what they

Rachel Cooke is Librarian for Languages $\mathcal{E}$ Literature, Fine $\mathcal{E}$ Performing Arts, and History, and Danielle Rosenthal is Science Librarian, both at Florida Gulf Coast University; e-mail: rcooke@fgcu.edu, drosenth@ fgcu.edu. 
liked about the presentation, and so forth. Although this information may help the librarian become a better presenter, it does not answer the key question, "Will this instruction influence what sources students use in their papers?" As it is said, "The proof is in the pudding."

So, two FGCU librarians decided to take a look at the pudding. In fall 2008, students from eight first-year Composition I classes at Florida Gulf Coast University participated in a study in which a librarian provided instruction to four classes (the experimental group) and provided no instruction to four other classes (the control group). The citation pages of the papers submitted by students were collected and analyzed. The results of this study revealed that the Composition I students who received instruction cited more books and cited fewer journals than students who did not receive instruction. The instructed students also cited more types of sources and more overall sources.

In addition, results from the Composition I experimental group were compared to those produced by students in upper-level classes (all of whom received instruction) to discern any differences between discipline-specific research. This interdisciplinary course comparison revealed that the number of citations per paper generally increased with class level, the percentage of scholarly citations generally increased with class level, and there was a high preference for books from all disciplines, especially history.

This article describes our study and the methodology. Specifically, the following citation characteristics were noted: 1) average number of citations per paper, 2) frequency of scholarly citations, and 3) frequency of source/format type. In addition, a brief review of the current literature indicates that the FGCU findings are similar to students' research behavior at other academic institutions across the country, although upper-level students at FGCU tend to use journal articles less frequently than students at other institutions. The students' observed preference for books over journal articles could be attributed to either the method of library instruction or the assignment itself. These discoveries serve as a baseline for future assessment of the library's information literacy program and future collaboration between librarians and faculty.

\section{Literature Review}

Academic libraries have been using citation analysis as a research methodology for at least forty years. In her 2005 study, Reba Leiding provides an excellent survey of the use of citation analysis in studies from the 1970s onward. Basically, these studies can be grouped into two categories: those designed to evaluate their collection's usefulness and those designed to evaluate collection use. Collection usefulness is usually, although not always, measured by examining citations in published theses, dissertations, and articles authored by the institution's graduate students and faculty. These can be a reliable means of measuring the usefulness of an academic collection, because it is likely that advanced researchers will know how to locate the most appropriate materials for their research, whether they are locally available or not. So, to evaluate collection usefulness, these types of citations, generated by scholars, are checked for such criteria as local availability, discipline, age, and format type. This information can be used to perform such tasks as adjusting budget allocations, updating certain collections, canceling subscriptions, and switching formats. ${ }^{1}$

When evaluating collection use or users' research behaviors, citations from users at different educational levels and academic disciplines can be examined to determine if users can locate sufficient and appropriate resources. This can be achieved by analyzing the quality and quantity of the sources, as well as their preferences for certain types of sources (such as online vs. print or books vs. articles). Results from this research can then be used to inform and improve information literacy programs. ${ }^{2}$ 
Some recent studies are briefly mentioned here for their relevance to the study at FGCU. All of the studies examine undergraduate student papers and have used the citation analysis method to inform information literacy programs or assess their collections. Randall McClure and Kellian Clink's study at Minnesota State University focused on whether firstyear students were using Internet-based sources versus more traditional sources such as books and journals, and how students evaluate sources. ${ }^{3}$ Jake Carlson's study at Bucknell University questioned whether course level, discipline, or the students' class year would have any effect on the sources students used. ${ }^{4}$ At James Madison University, Leiding collected citation information (such as discipline and format) from undergraduate theses to identify usage patterns and assess the library's collection. ${ }^{5}$ The largest study represented is by David H. Mill, who analyzed 236 papers from 64 upperlevel courses in 17 disciplines at Ursinus College. Mill's study focused on several citation characteristics, including source, format, age, and library availability to assess both the libraries' collections and services. ${ }^{6}$ Finally, Stacey Knight-Davis and Jan S. Sung at Eastern Illinois University examined what source type and format students were citing and if these materials were housed in their library. They used these data to assess both their collection and their information literacy program. ${ }^{7}$

As discussed later, data from these studies have been extracted and compared to the FGCU experiment. Although it may appear that these findings benefit only the home institutions, when the results are compared, certain trends in student research behavior emerge that could inform other academic libraries' information literacy programs.

\section{Methodology (The Composition I Study)}

This quantitative experiment examined average number of citations per paper, frequency of scholarly citations, and frequency of source/format type in papers written by undergraduates who have received in-class library instruction. Library instruction is the independent variable and the citations were the dependent variable. There was an experimental group (students who had received instruction) and a control group (students who had not received instruction).

All of the participants in this study were students enrolled in the fall Composition I courses. Typically, these are firstsemester students with no prior academic library experience. All of the students were voluntary participants and were assigned a research paper by their professor. Although the assignments were not strictly identical, typically students would first write essays about social issues in which they were interested (for example, rising college tuition, artificial sweeteners, or effect of television on children) and then revise their essays to include outside sources that support their theses. Only a few sources were required (usually fewer than 5 , sometimes only 1 ). However, all of the students were required to use at least one scholarly source (defined below) and were allowed to use one Web site.

Four classes received in-class library instruction (the experimental group) and four classes did not (the control group). All of the students receiving instruction were taught by the same librarian in the library's information literacy lab, which provided computers for hands-on interaction. The instruction lasted about one hour and emphasized finding books and journal articles. For the first fifteen minutes, the librarian discussed general library resources and services, including such topics as library hours, the reference desk, online chat, online research guides, tutorials, and MLA resources. Twenty to twenty-five minutes were spent on the library catalog, including how to search by subject and keyword, how to generate MLA citations from the catalog, and how to locate items on the shelf. Twenty minutes were spent on database search- 


\section{TABLE 1}

\section{Comparison of Composition 1 Classes-Average Citations per Paper}

\begin{tabular}{|l|c|c|c|c|}
\hline & $\begin{array}{c}\text { Number of } \\
\text { Sections }\end{array}$ & $\begin{array}{c}\text { Number of } \\
\text { Papers }\end{array}$ & $\begin{array}{c}\text { Number of } \\
\text { Citations }\end{array}$ & $\begin{array}{c}\text { Average Citations } \\
\text { per Paper }\end{array}$ \\
\hline No Instruction & 4 & 75 & 239 & 3.2 \\
\hline Instruction & 4 & 66 & 352 & 5.3 \\
\hline
\end{tabular}

ing, usually Proquest Research Library and CQ Researcher, although others were demonstrated depending on the students' topics and available time.

Later in the semester, the bibliography pages from the students' papers were collected and analyzed. A citation analysis was performed on these bibliographies. The rest of the paper was not analyzed. The data were recorded in an SPSS file, and descriptive statistics, including the frequency of each variable, were calculated with the SPSS program.

Librarians analyzing the data were usually able to discern the source type and if the material was scholarly ${ }^{8}$ by the source title. If uncertain, the librarian referred to Ulrich's International Periodicals Directory or a book review database. In general, nearly all the books, journal articles, and government documents were deemed scholarly. Nonscholarly materials included magazines, videos, nongovernment Web sites, and other types such as interviews.

\section{Limitation of the Study}

It must be mentioned that one limitation of the study is that students in the "No Instruction" group may have received research help from other sources such as their professor or an in-class library session offered in another class. In fact, the students were not blocked from using any of the library's services: the library reference desk, online chat, research consultations, or walk-in library workshops. However, these services are self-directed. The Composition I faculty teaching the "No Instruction" groups did not require students to use these services. So, despite this limitation, the researchers felt confident that the final data would accurately reflect the effect of instruction on student research behavior.

\section{Results}

Table 1 shows the average citations per paper from the "No Instruction" and "Instruction" groups. The data reveal that students receiving instruction cited more sources in their papers (5.3 sources vs. 3.2 sources).

In addition to the number of citations per paper, the citations were analyzed for certain characteristics. Table 2 shows the frequency of scholarly citations. Instruction did appear to contribute to a slight increase in the number of scholarly citations $(51.7 \%$ in the "Instruction" group vs. $49.4 \%$ in the "No Instruction" group). As mentioned earlier, a typical Composition I assignment at FGCU requires at least one scholarly source and allows at least one Web site. (Additional nonscholarly material may have been completely appropriate depending on the student's paper topic.) It is likely the

\section{TABLE 2}

Comparison of Composition I Classes-Frequency of Scholarly Citations

\begin{tabular}{|l|c|c|c|c|c|}
\hline Instruction? & $\begin{array}{c}\text { Scholarly } \\
\text { Citations }\end{array}$ & $\begin{array}{c}\text { Non- } \\
\text { Scholarly } \\
\text { Citations }\end{array}$ & $\begin{array}{c}\text { Other/ } \\
\text { Unknown } \\
\text { Citations }\end{array}$ & $\begin{array}{c}\text { No } \\
\text { Citation } \\
\text { Page }\end{array}$ & $\begin{array}{c}\text { Total } \\
\text { Number of } \\
\text { Citations }\end{array}$ \\
\hline NO Instruction & $49.4 \%(118)$ & $43.9 \%(105)$ & $3.8 \%(9)$ & $2.9 \%(7)$ & 239 \\
\hline Instruction & $51.7 \%(182)$ & $47.4 \%(167)$ & $.9 \%(3)$ & $0 \%(0)$ & 352 \\
\hline
\end{tabular}


students followed the parameters of the assignment without much deviation, and it is encouraging that even the students who did not receive instruction knew how to access scholarly materials, either from previous experiences in high school or from a source other than a library session (such as their professor, the reference desk, or a research consultation with a librarian). It is interesting to note, though, that all of the papers from the "Instruction" group had a citation page, while 2.9 percent of the "No Instruction" group did not create one.

Although there was not much difference in terms of scholarly citations, there was a significant difference in terms of source/format type (table 3). Students receiving instruction were far more likely to cite book sources (overall $25.6 \%$ vs. $6.3 \%$ ). Students who did not receive instruction used more journal articles (overall 27.3\% vs. $16.3 \%$ ). The use of Web sites was about the same (overall 31\%) for both groups.

Why did book use increase? The preference for books among the instruction group could be attributed to library instruction. During the instruction session, the librarian encouraged students to look first for books, which provide a broader coverage of their topic, and then search for articles, which tend to be very narrow in scope. After demonstrating the book searches, the librarian would teach article searching via databases such as Proquest Research Library. If the students followed the same steps in their research, they may have found good sources of information via books in the catalog. The low journal usage among the "Instruction" group is not necessarily a negative. Many Composition I paper topics tend to be broad in scope, and journal articles would be too specialized for some topics. Still, the librarian encouraged the students to use both books and journal articles in their research. It is also encouraging to see that even students who did not receive instruction used a high number of journals in their citations, which again might be attributed to previous high school experi- ence, their professor's help, or assistance from one of the library's services.

Table 3 also indicates whether the source was accessed via print, online database, or unknown. All of the book and journal citations were entered in the library catalog to determine whether the FGCU library owned the book or journal title. If both formats were available, or the item was not owned by FGCU, the citation would fall into the "unknown" category. There is an assumption that the student is accessing the resource from the FGCU Library; the likelihood of the student using another library is probably low because the FGCU Library is the largest and most comprehensive academic library in Lee County as well as the surrounding five-county area.

The source format was of special interest because of the growing availability of online resources such as e-books and e-journals. The FGCU library owns approximately 2,000 journals in print on the shelf, but users can access more than 40,000 journals online; FGCU owns over 300,000 books, 70,000 of which are available online. The results reveal that both groups of students preferred to access their books in print and their journals, magazines, and newspapers online.

Web sites were the most frequently cited resource for both groups, accounting for about a third of all the citations. Students in the "No Instruction" group were twice as likely to use videos and to rely more on the course text or course handout than did the "Instruction" group.

It was also observed that many composition students tended to use one resource exclusively - either Web sites only, books only, or databases only. As discussed earlier, research papers assigned to composition students usually require only a few sources (typically fewer than 5 , sometimes only 1). Thus, students already in the catalog, surfing the Internet, or logged on to a database may find that it is more efficient to complete all their research using one search tool. In addition, these 


\begin{tabular}{|c|c|c|c|}
\hline \multicolumn{4}{|c|}{$\begin{array}{c}\text { TABLE } 3 \\
\text { Comparison of Composition I Classes - Frequency of Source/Format Type }\end{array}$} \\
\hline Source & Format & No Instruction & Instruction \\
\hline \multirow[t]{3}{*}{ Books } & Print & $2.5 \%(6)$ & $17.9 \%(63)$ \\
\hline & Online Database & $0 \%(0)$ & $2.3 \%(8)$ \\
\hline & Unknown & $3.8 \%(9)$ & $5.4 \%(19)$ \\
\hline \multirow[t]{3}{*}{ Journals } & Print & $1.3 \%(3)$ & $.9 \%(3)$ \\
\hline & Online Database & $24.7 \%(59)$ & $15.1 \%(53)$ \\
\hline & Unknown & $1.3 \%(3)$ & $.3 \%(1)$ \\
\hline \multirow[t]{2}{*}{ Reference Source } & Print & $.8 \%(2)$ & $0 \%(0)$ \\
\hline & Online Database or Web & $0 \%(0)$ & $.9 \%(3)$ \\
\hline \multirow{3}{*}{$\begin{array}{l}\text { Magazines \& } \\
\text { Newspapers }\end{array}$} & Print & $.8 \%(2)$ & $1.1 \%(4)$ \\
\hline & Online Database or Web & $9.6 \%(23)$ & $18.5 \%(65)$ \\
\hline & Unknown & $.4 \%(1)$ & $.6 \%(2)$ \\
\hline Course text or handout & Print & $11.7 \%(28)$ & $0 \%(0)$ \\
\hline \multirow[t]{3}{*}{ Web } & .com or .org & $23 \%(55)$ & $21.6 \%(76)$ \\
\hline & .gov or .edu & $5 \%(12)$ & $5.1 \%(18)$ \\
\hline & Other & $2.9 \%(7)$ & $4.0 \%(14)$ \\
\hline Media & TV, Video, or DVD & $5.4 \%(13)$ & $2.8 \%(10)$ \\
\hline Interview & Interview & $.8 \%(2)$ & $.9 \%(3)$ \\
\hline Other & & $2.9 \%(7)$ & $2.8 \%(10)$ \\
\hline No Citation Page & & $2.9 \%(7)$ & $0 \%(0)$ \\
\hline Total & & $99.8 \%(239)$ & $100.2 \%(352)$ \\
\hline \multicolumn{4}{|c|}{$\begin{array}{l}\text { Note: } \\
\text { - Books include reference publications. } \\
\text {-Unknown" books, journals, newspapers, and magazines are those in which the format could not } \\
\text { be determined - the item was available in both formats at FGCU or was not available at FGCU. } \\
\text { The total is rounded to the nearest tenth of a percent. }\end{array}$} \\
\hline
\end{tabular}

students are usually allowed to use nonscholarly sources for their research, such as Web sites, as long as the site is authoritative. Generally, students are encouraged to use .edu and .gov sites, although .com and .org sites may be acceptable depending on factors of the site such as authority, accuracy, currency, and relevancy.

\section{Methodology (The Interdisciplinary Course Comparison Study)}

In addition to the Composition I study, the results from the Composition I experimental group were compared to other upper-level classes that had received library instruction to discern any differ- ences in citation behavior among disciplines. The citation analysis measured the same variables as in the Composition I study and were calculated with an SPSS file. These upper-level classes included a 300 level History class, a 400 level History class, a 200 level Art History class, a 400 level Art Class, and a 300 level English class. (The 200, 300, and 400 levels are loosely equivalent to Sophomore, Junior, and Senior level.) As is typical in library science research, librarians must limit their research to faculty who volunteer to participate; this explains the somewhat eclectic group of classes. Nevertheless, the results provide some useful data on the 
research behaviors of students from different class levels and disciplines.

\section{Results}

The average number of citations for each paper is shown in table 4 . The average citations per paper generally increased with class level within the discipline. The Art 400 level class, with an average of 33.3 citations per paper, had completed a senior project requiring an extensive bibliography, which explains the relative abundance of citations as compared with the other disciplines. It must be noted that the number of papers analyzed was considerably smaller for the upper-level classes. At FGCU, upper-level classes tend to be quite small; the 400 level Art class had 6 students. Also, in each class, there were always a few students who declined to participate; among those who volunteered, some students did not turn in a final paper or withdrew from the class.
The different classes were also compared in terms of the frequency of scholarly citations (table 5). The Composition I students had the highest percentage of nonscholarly citations (47\%). The percentage of scholarly citations generally increased with class level, the History 400 level class having the highest percentage (96\%). The high number of nonscholarly citations in the Art 400 level class (41\%) is explained by their preference for .com/. org Web sites (33\%, see table 6). In this case, Web sites were appropriate, because students were researching emerging living artists who had not yet reached the level of recognition that would attract academic inquiry.

In terms of source/format type (table 6), the researchers discovered a high preference for books from all of the classes, especially the History 300 and 400 level classes $(71 \%$ and $81 \%)$. In general, journal use was much lower for most of the

TABLE 4

Interdisciplinary Course Comparison-Average Citations per Paper

\begin{tabular}{|l|c|c|c|c|}
\hline Discipline \& level & $\begin{array}{c}\text { Number of } \\
\text { Classes }\end{array}$ & $\begin{array}{c}\text { Number of } \\
\text { Papers }\end{array}$ & $\begin{array}{c}\text { Number of } \\
\text { Citations }\end{array}$ & $\begin{array}{c}\text { Average Citations } \\
\text { per Paper }\end{array}$ \\
\hline Composition I & 4 & 66 & 352 & 5.3 \\
\hline History 300 level & 1 & 7 & 85 & 12.1 \\
\hline History 400 level & 1 & 2 & 26 & 13 \\
\hline Art History, 200 level & 2 & 29 & 297 & 10.2 \\
\hline Art, 400 level & 1 & 3 & 100 & $33.3 *$ \\
\hline English, 300 level & 2 & 18 & 118 & 6.6 \\
\hline *The Art 400 level class was a senior project requiring an extensive bibliography. \\
\hline
\end{tabular}

\begin{tabular}{|l|c|c|c|c|}
\hline \multicolumn{5}{|c|}{ TABLE 5 } \\
\hline Interdisciplinary Course Comparison-Frequency of Scholarly Citations \\
\hline Course & $\begin{array}{c}\text { Scholarly } \\
\text { Citations }\end{array}$ & $\begin{array}{c}\text { Non-Scholarly } \\
\text { Citations }\end{array}$ & $\begin{array}{c}\text { Other/Unknown } \\
\text { Citations }\end{array}$ & $\begin{array}{c}\text { Total Number } \\
\text { of Citations }\end{array}$ \\
\hline Composition I & $52 \%(182)$ & $47 \%(167)$ & $1 \%(3)$ & 352 \\
\hline History 300 level & $85 \%(72)$ & $13 \%(11)$ & $2 \%(2)$ & 85 \\
\hline History 400 level & $96 \%(25)$ & $0 \%(0)$ & $4 \%(1)$ & 26 \\
\hline Art History, 200 level & $68 \%(201)$ & $32 \%(96)$ & $0 \%(0)$ & 297 \\
\hline Art, 400 level & $59 \%(59)$ & $41 \%(41)$ & $0 \%(0)$ & 100 \\
\hline English, 300 level & $90 \%(106)$ & $10 \%(12)$ & $0 \%(0)$ & 118 \\
\hline
\end{tabular}


classes, although it was especially low in the History 400 level class (4\%) and especially high in the English 300 level class (43\% overall). The Art History 200 level students had a particularly high preference for reference sources (19\% overall). Their research required biographical information on artists, so this is not surprising. As discussed earlier, Web sites were frequently cited in the Composition I and Art 400 level classes.

Besides the English and Composition I courses, online journal use was relatively low. In fact, the History 400 level students did not use any online journals offered by FGCU. Again, perhaps this can be partially explained by the assignment: history students are required to use a certain number of primary sources, which come in the form of books or Web sites. Government documents and primary source digital collections, like the Internet History Sourcebook at Fordham University, were especially popular. And, as mentioned earlier, the Art History students were researching emerging living artists who had not yet appeared in academic publications, such as journal articles.

When considering Internet usage, Web .com and .org sites were popular choices for the Composition I, Art History, and Art students, which, as explained earlier, correspond with the nature of the assignments. Wikipedia was not a frequently cited source among the .com Web sites cited. It only appeared four times: thrice in the Composition I classes and once in the 300 level History class. Conversations with professors indicated that they discourage students from citing Wikipedia, and the results support the success of that.

Overall, the researchers were encouraged that the frequency of scholarly materials increased with class level and were pleased that students from all disciplines were using book sources, which provide broader, more in-depth information on students' topics. The researchers suspected that journal articles would be more popular since they are shorter to read and can be easily accessed at home through the library's Web site. However, journal use among the classes tended to be relatively low ( $17 \%$ or lower) except for the English 300 level, which was 43 percent overall, almost equal to the use of books.

\section{Comparison to Other Citation Analysis Studies}

The question remains, "Are these results typical?" A brief review of recent studies indicates that the FGCU findings are not much different from students' research behaviors as noted at other academic institutions across the country. Table 7 summarizes some of the results of citation analysis at other U.S. colleges and universities (mentioned earlier in the literature review), and compares it with the FGCU study. The frequency of books, journals, Web sites, and "other" has been extracted from these studies to give a simple review. For ease of comparison, data from the FGCU 200 level Art History class were omitted. Only data from the lower-level classes (Composition I) and the upperlevel (300 and 400 level) classes were used, because those represented similar categories used by other universities.

As discussed earlier, all five citation analysis studies represented in table 7 are sufficiently similar to the FGCU study to allow a compatible comparison. Overall, the data from table 7 reveal that book usage is also popular with students from other universities. In fact, non-FGCU students use book sources for $27 \%-54 \%$ of their citations. Journal article usage is closely matched at the higher level classes, with students using journal articles for $24 \%-48 \%$ of their citations.

One striking similarity was noted when comparing the first-year composition student papers from FGCU and those from Minnesota State University: in both universities, students used books for $26 \%-29 \%$ of their citations and journal articles were hardly used at all-a mere 16 percent. Web site usage did differ; at Minnesota State, students used a Web site 


\begin{tabular}{|c|c|c|c|c|c|c|c|}
\hline \multicolumn{8}{|c|}{$\begin{array}{c}\text { TABLE } 6 \\
\text { Interdisciplinary Course Comparison-Frequency of Source/Format Type }\end{array}$} \\
\hline Source & Format & Comp I & $\begin{array}{c}\text { History } \\
300 \text { level }\end{array}$ & $\begin{array}{c}\text { History } \\
400 \text { level }\end{array}$ & $\begin{array}{c}\text { Art } \\
\text { History } \\
200 \text { level }\end{array}$ & $\begin{array}{c}\text { Art } 400 \\
\text { level }\end{array}$ & $\begin{array}{c}\text { English } \\
300 \text { level }\end{array}$ \\
\hline \multirow[t]{3}{*}{ Books } & Print & $\begin{array}{c}17.9 \% \\
(63)\end{array}$ & $\begin{array}{c}49.4 \% \\
(42)\end{array}$ & $\begin{array}{c}19.2 \% \\
(5)\end{array}$ & $\begin{array}{c}28.6 \% \\
(85)\end{array}$ & $\begin{array}{l}33 \% \\
(33)\end{array}$ & $\begin{array}{c}29.7 \% \\
(35)\end{array}$ \\
\hline & $\begin{array}{l}\text { Online } \\
\text { Database }\end{array}$ & $\begin{array}{c}2.3 \% \\
(8)\end{array}$ & $1.2 \%(1)$ & $\begin{array}{c}30.8 \% \\
(8)\end{array}$ & $1.3 \%(4)$ & $1 \%(1)$ & $1.7 \%(2)$ \\
\hline & Other & $\begin{array}{c}5.4 \% \\
(19)\end{array}$ & $\begin{array}{l}20 \% \\
(17)\end{array}$ & $\begin{array}{c}30.8 \% \\
(8)\end{array}$ & $\begin{array}{c}9.8 \% \\
(29)\end{array}$ & $5 \%(5)$ & $\begin{array}{c}11.9 \% \\
(14)\end{array}$ \\
\hline \multirow[t]{3}{*}{ Journals } & Print & $.9 \%(3)$ & $0 \%(0)$ & $0 \%(0)$ & $0 \%(0)$ & $0 \%(0)$ & $0 \%(0)$ \\
\hline & $\begin{array}{l}\text { Online } \\
\text { Database }\end{array}$ & $\begin{array}{c}15.1 \% \\
(53)\end{array}$ & $\begin{array}{c}14.1 \% \\
(12)\end{array}$ & $0 \%(0)$ & $\begin{array}{c}12.1 \% \\
(36)\end{array}$ & $\begin{array}{l}12 \% \\
(12)\end{array}$ & $\begin{array}{c}35.6 \% \\
(42)\end{array}$ \\
\hline & Other & $.3 \%(1)$ & $0 \%(0)$ & $3.8 \%$ & $\begin{array}{l}5.1 \% \\
(15)\end{array}$ & $2 \%(2)$ & $7.6 \%(9)$ \\
\hline \multirow{2}{*}{$\begin{array}{l}\text { Reference } \\
\text { Source }\end{array}$} & Print & $0 \%(0)$ & $0 \%(0)$ & $0 \%(0)$ & $.7 \%(2)$ & $2 \%(2)$ & $0 \%(0)$ \\
\hline & $\begin{array}{l}\text { Online } \\
\text { Database } \\
\text { or Web }\end{array}$ & $.9 \%(3)$ & $0 \%(0)$ & $0 \%(0)$ & $\begin{array}{c}18.2 \% \\
(54)\end{array}$ & $4 \%(4)$ & $3.4 \%(4)$ \\
\hline \multirow[t]{3}{*}{$\begin{array}{l}\text { Magazines \& } \\
\text { Newspapers }\end{array}$} & Print & $\begin{array}{c}1.1 \% \\
(4)\end{array}$ & $0 \%(0)$ & $0 \%(0)$ & $.3 \%(1)$ & $0 \%(0)$ & $0 \%(0)$ \\
\hline & $\begin{array}{l}\text { Online } \\
\text { Database } \\
\text { or Web }\end{array}$ & $\begin{array}{l}18.5 \% \\
(65)\end{array}$ & $0 \%(0)$ & $0 \%(0)$ & $\begin{array}{l}8.8 \% \\
(26)\end{array}$ & $3 \%(3)$ & $.8 \%(1)$ \\
\hline & Other & $.6 \%(2)$ & $0 \%(0)$ & $0 \%(0)$ & $2.4 \%(7)$ & $0 \%(0)$ & $2.5 \%(3)$ \\
\hline $\begin{array}{l}\text { Course Text } \\
\text { or handout }\end{array}$ & Print & $0 \%(0)$ & $0 \%(0)$ & $0 \%(0)$ & $0 \%(0)$ & $0 \%(0)$ & $.8 \%(1)$ \\
\hline \multirow[t]{3}{*}{ Web } & $\begin{array}{l}. c o m \text { or } \\
.0 r g\end{array}$ & $\begin{array}{c}21.6 \% \\
(76)\end{array}$ & $4.7 \%(4)$ & $0 \%(0)$ & $\begin{array}{l}5.7 \% \\
(17)\end{array}$ & $\begin{array}{l}33 \% \\
(33)\end{array}$ & $0 \%(0)$ \\
\hline & $\begin{array}{l}\text {.gov or } \\
\text {.edu }\end{array}$ & $\begin{array}{l}5.1 \% \\
(18)\end{array}$ & $7.1 \%(6)$ & $\begin{array}{l}15.4 \% \\
(4)\end{array}$ & $1.7 \%(5)$ & $2 \%(2)$ & $.8 \%(1)$ \\
\hline & Other & $\begin{array}{c}4.0 \% \\
(14)\end{array}$ & $0 \%(0)$ & $0 \%(0)$ & $1.7 \%(5)$ & $2 \%(2)$ & $0 \%(0)$ \\
\hline Media & $\begin{array}{l}\text { TV, video, } \\
\text { or DVD }\end{array}$ & $\begin{array}{c}2.8 \% \\
(10) \\
\end{array}$ & $0 \%(0)$ & $0 \%(0)$ & $0 \%(0)$ & $1 \%(1)$ & $2.5 \%(3)$ \\
\hline Inter-view & Interview & $.9 \%(3)$ & $3.5 \%(3)$ & $0 \%(0)$ & $0 \%(0)$ & $0 \%(0)$ & $0 \%(0)$ \\
\hline Other & & $\begin{array}{c}2.8 \% \\
(10)\end{array}$ & $0 \%(0)$ & $0 \%(0)$ & $\begin{array}{c}3.7 \% \\
(11)\end{array}$ & $0 \%(0)$ & $2.5 \%$ \\
\hline Total & & $\begin{array}{c}100.2 \% \\
(352)\end{array}$ & $\begin{array}{c}100 \% \\
(85)\end{array}$ & $\begin{array}{c}100 \% \\
(26)\end{array}$ & $\begin{array}{c}100.1 \% \\
(297)\end{array}$ & $\begin{array}{l}100 \% \\
(100)\end{array}$ & $\begin{array}{c}99.8 \% \\
(118)\end{array}$ \\
\hline \multicolumn{8}{|c|}{$\begin{array}{l}\text { Note: } \\
\text { - Books include reference publications. } \\
\text {-Other" books, journals, newspapers, and magazines are those in which the format could not be } \\
\text { determined - the item was available in both formats at FGCU or was not available at FGCU. } \\
\text { The total is rounded to the nearest tenth of a percent. }\end{array}$} \\
\hline
\end{tabular}


for nearly half of their citations, while FGCU students used them for only a third of their citations. ${ }^{9}$ The low journal usage among first-year students is not at all surprising, since they have probably used books in high school but have limited experience with databases and online journals.

It is interesting to note that, when considering the upper-level classes, the FGCU study is particularly close to Carlson's study at Bucknell University. At Bucknell, students cited books twice as frequently as articles. Even the percentages were similar: 52 percent of the FGCU citations were books; at Bucknell, it was 54 percent. Students from both universities also used a similar proportion of Web sites: $9 \%-16 \%{ }^{10}$

The numbers start to differ a bit when comparing the FGCU study to studies completed by Leiding, Mill, and KnightDavis and Sung. According to Leiding, students at James Madison preferred journals to books. They cited journals for 42 percent and books for 34 percent of their citations. ${ }^{11}$ This preference for journals was even more pronounced in Mill's study at Ursinus College, where students cited journals for 48 percent of their citations and books for only 30 percent. Interestingly, even though these were upper-level classes, the use of Web sites was particularly high, at 17 percent. $^{12}$ Citing of Web sites was even higher for Eastern Illinois University, the study completed by Knight-Davis and Sung, which also demonstrated a preference for journals. ${ }^{13}$

\section{Conclusion}

The results of this study support continuing library instruction to the Composition I students. When students receive in-class library instruction, they cite more sources and more types of sources-especially books. Overall, students tend to prefer to read books in print format and journal articles online, although this may be because the FGCU collection has more print than electronic books and more electronic than print journals. Also, it may be interesting to know if students are printing out their online articles before they read them. Additional research in this area is needed to know for certain whether students prefer print or online resources.

Although it is disappointing that there was no significant increase in scholarly material cited among the students receiving instruction, that may be explained by the assignment and also the self-directed efforts of the control-group students in finding adequate support from their professor or the library's walk-in services to locate as many scholarly sources as their assignments required.

In addition, it was encouraging to discover that these students, as they progress to higher-level classes and continue to receive instruction, use more citations per paper, use more scholarly citations, and continue to use (even prefer) book sources even as online journals and the Internet sources are becoming easier to access.

These results are supported by similar studies across the country. A comparison to other institutions of higher learning demonstrates that the FGCU students are similar to other students across the United States in that they are relying on traditional sources like books and, at least among the higher level classes, do not rely heavily on Web sites. The only remarkable difference is that the FGCU students were at the lower end of the percentage of journal articles cited, similar to the students at Bucknell. Although it is encouraging that students are using book sources, there is a concern that the low journal usage may mean that students' sources are not as diverse as they could be and that students could be missing some of the newer secondary research that is available, as books are generally older because of the longer interval between writing and publication.

So why did the FGCU students prefer books over journal articles? This preference could be attributed to the method of library instruction or the assignment itself. Because the librarian begins with catalog searching, there is perhaps more 
TABLE 7

Interdisciplinary Course Comparison-Comparison of Citation Analysis at

U.S. Colleges and Universities (Percentages rounded up to the nearest whole number)

\begin{tabular}{|c|c|c|c|c|c|c|}
\hline Author & University & Data Analyzed & $\begin{array}{l}\text { Books } \\
\text { Cited }\end{array}$ & $\begin{array}{c}\text { Journal } \\
\text { Articles } \\
\text { Cited }\end{array}$ & $\begin{array}{l}\text { Websites } \\
\text { Cited }\end{array}$ & Other \\
\hline $\begin{array}{l}\text { Cooke \& } \\
\text { Rosenthal }\end{array}$ & \begin{tabular}{|l|} 
Florida \\
Gulf Coast \\
University \\
\end{tabular} & $\begin{array}{l}66 \text { papers from first year } \\
\text { English Composition I } \\
\text { students, } 2008 \\
\end{array}$ & $26 \%$ & $16 \%$ & $31 \%$ & $27 \%$ \\
\hline $\begin{array}{l}\text { McClure } \\
\& \text { Clink }^{14}\end{array}$ & $\begin{array}{l}\text { Minnesota } \\
\text { State } \\
\text { University }\end{array}$ & $\begin{array}{l}100 \text { essays from first year } \\
\text { English Composition } \\
\text { students, } 2008\end{array}$ & $29 \%$ & $16 \%$ & $48 \%$ & $7 \%$ \\
\hline $\begin{array}{l}\text { Cooke \& } \\
\text { Rosenthal }\end{array}$ & $\begin{array}{l}\text { Florida } \\
\text { Gulf Coast } \\
\text { University }\end{array}$ & $\begin{array}{l}30 \text { papers from } 300 \& \\
400 \text { level courses in His- } \\
\text { tory, Art, and English, } \\
2008\end{array}$ & $52 \%$ & $24 \%$ & $16 \%$ & $8 \%$ \\
\hline Carlson $^{15}$ & $\begin{array}{l}\text { Bucknell } \\
\text { University }\end{array}$ & $\begin{array}{l}77 \text { papers from } 300 \& \\
400 \text { levels, all disciplines, } \\
2002\end{array}$ & $54 \% *$ & $24 \% *$ & $9 \% *$ & $13 \% *$ \\
\hline Leiding $^{16}$ & \begin{tabular}{|l|} 
James \\
Madison \\
University \\
\end{tabular} & $\begin{array}{l}101 \text { undergraduate honors } \\
\text { theses, 1997-2007 }\end{array}$ & $34 \%$ & $42 \%$ & $10 \%$ & $14 \%$ \\
\hline Mill $^{17}$ & $\begin{array}{l}\text { Ursinus } \\
\text { College }\end{array}$ & $\begin{array}{l}236 \text { papers from } 64 \\
\text { intermediate \& advanced } \\
\text { courses, 2004-2005 } \\
\end{array}$ & $30 \%$ & $48 \%$ & $17 \%$ & $6 \%$ \\
\hline $\begin{array}{l}\text { Knight- } \\
\text { Davis \& } \\
\text { Sung }^{18}\end{array}$ & $\begin{array}{l}\text { Eastern } \\
\text { Illinois } \\
\text { University }\end{array}$ & $\begin{array}{l}140 \text { papers from } 3000 \text { or } \\
4000 \text { writing-centered } \\
\text { courses, } 2000-2005\end{array}$ & $27 \%$ & $39 \%$ & $20 \%$ & $13 \%$ \\
\hline
\end{tabular}

(or too much?) emphasis on that research tool. One solution would be for the librarian to spend less time demonstrating the catalog searches and more time with database searching. Another solution would be to break up the library instruction into two sessions. One session could focus on using the catalog to find books and the other session on using databases to find journal articles. Of course, even if the sessions were short, this may not be practical for some libraries if staffing levels are low and libraries are trying to "do more with less," but it may work in some cases.

The assignments also may have played a role, since many professors, especially history professors, require a minimum number of primary resources and most of these have been coded as books in this study. Even though the number of journal citations seemed somewhat low from a librarian's perspective, it could actually be right on target from the professor's viewpoint. Informal, follow-up conversations with the participating professors have generally supported this. They are pleased that students are "going to the shelf" and encourage students to use books in their research.

At least for now, FGCU librarians will continue to offer traditional in-class library instruction, and it is reassuring to know that this effort is making a difference in 
student papers. Of course, one wonders if the in-class library instruction model will continue as more classes go online. Perhaps this instruction will evolve into Webinars for those classes that would benefit from live instruction. Plans are now underway to evaluate our online tutorials, chat, research guides, and other Web tools. Ongoing assessment will continue to be important as we face the challenges and opportunities of working in one of the fastest-growing universities in the country.

\section{Notes}

1. Reba Leiding, "Using Citation Checking of Undergraduate Honors Thesis Bibliographies to Evaluate Library Collections," College $\mathcal{E}$ Research Libraries 66, no. 5 (Sept. 2005): 418-19.

2. Leiding, "Using Citation Checking," 418-19.

3. Randall McClure and Kellian Clink, "How Do You Know That? An Investigation of Student Research Practices in the Digital Age," portal: Libraries and the Academy 9, no. 1 (2009): 115.

4. Jake Carlson, "An Examination of Undergraduate Student Citation Behavior," Journal of Academic Librarianship 32, no. 1 (Jan. 2006): 14.

5. Leiding, "Using Citation Checking," 417.

6. David H. Mill, "Undergraduate Information Resource Choices," College \& Research Libraries 69, no. 4 (July 2008): 342.

7. Stacey Knight-Davis and Jan S. Sung, "Analysis of Citations in Undergraduate Papers," College \& Research Libraries 69, no. 5 (Sept. 2008): 447.

8. For the purpose of this study, "scholarly" referred to any material that met the following three criteria: 1) "written by experts/professionals in a specific field," 2) "published by a recognized society with academic goals and missions," and 3) "deals with academic study and research in its field." Florida Gulf Coast University Library Services, "Identifying Scholarly Journals, Peer Reviewed/Refereed, Journals, Magazines, and Trade Publications," handout, Aug. 2005.

9. McClure and Clink, "How Do You Know That?" 119.

10. Carlson, "An Examination of Undergraduate Student Citation Behavior," 18.

11. Leiding, "Using Citation Checking," 423.

12. Mill, "Undergraduate Information Resource Choices," 346.

13. Knight-Davis and Sung, "Analysis of Citations in Undergraduate Papers," 451.

14. McClure and Clink, "How Do You Know That?" 119.

15. Carlson, "An Examination of Undergraduate Student Citation Behavior," 18.

16. Leiding, "Using Citation Checking," 423.

17. Mill, "Undergraduate Information Resource Choices," 346.

18. Knight-Davis and Sung, "Analysis of Citations in Undergraduate Papers," 451. 